\title{
FOREIGN NEWS
}

\author{
in Chamog of
}

LAVINIA L. DOCK

\section{ORGANIZATION NOTES AND CURRENT EVENTS}

WE welcome the news of a newly founded club of nurses in Dublin. Our special correspondent wrote us of it, also Miss Huxley, matron of St. Patrick Dun's Hospital, in Dublin, who promiscs us some later items regarding it.

The editor is in receipt of a cordial letter from the secretary of the new association in Holland which we have mentioned before. It will exchange jour. nals with $u s$, and we believe that in its members we have found friends. We hope to see some of them at the Buffalo Congress.

Extremely interesting and important are the newest developments in organization in England, as noted below by our English correspondent.

\section{LETTERS}

\section{FROM OUR ENGLISH CORRESPONDENT}

Dear Editor: Since my last letter $I$ have received the two numbers of The American Jourval of Nunsina, and must tell you how much pleasure their perusal has given me. Most of all, I am glad to find that, like our own Nursing Record, it rings true on the subject of State registration, and, as I have learned to believe that American nurses, when they desire a thing, generally manage to obtain it, I shall watel with the greatest interest your progress towards the attainment of this measure, of vital interest to nurses the world over, for it means no less than their professional enfranchisement.

\section{STATE REGISTRATION.}

The friends of State registration here were delighted that Miss Louisa Stevenson, a member of the Board of Management of the Edinburgh Royal Infirmary and a vice-president of our National Council of Women, endorsed it in an able paper on "The Work of Women on Hospital Boards," which she read at the recent conference of the National Council of Women at Brighton.

Miss Stevenson does not express her adhesion to any scheme until she has given it her careful consideration, and, as her judgment is much respected, her publicly expressed conviction on this subject is very encouraging. She said: "Nurses, however well trained, however efficient physically, mentally, and morally, will never ohtain either the position or the pay to which the best are entitled until the public has the means of differentiating between the good and the bad, between those claiming high pay and those claiming lower, by 
some other means tban pleasant or painful experience, as tbe case may be, in time of sickness or distress.

"After much consideration, I have come to the conclusion that the remedy for the present unsatisfactory state of things will be found in a comprehensive system of State registration for nurses. This in the interests of the State, the general public, hospitals and private patients, and of tbe nurses themselves.

"To formulate such a system will require the help of the very best of those women who have knowledge and experience in nursing matters. It must, as I said, be comprehensive, and must not be grown in a mould, but be planted like a tree and allowed to develop in the sunshine of good mental and moral influences.

"Examination for admission to such register should be 'pass,' not competitive, and should be intrusted to some extent to nurses of position and experience.

"Pending registration, every hospital certificate should set forth the duration of each branch of the training given, so that employers may be able to judge if a nurse has had tbe experience qualifying her to take the care of any special case."

A second question discussed at the Brighton Conference of importance to the nurses of all nations was brought forward in the following resolution by the Countess of Aberdeen :

REPRESENTATION ON THE INTERNATIONAL COUNCIL OF WOMEN.

" Tbat it is desirable that National Councils be accorded a larger representation upon the International Council at its business meetings, and that an expression of the opinion of this council upon the subject be sent to the president of the International Council, in order that it may be placed upon the agenda of the Quinquennial Council meeting in 1904."

Mrs. Bedford Fenwick supported the resolution and considered it eminently desirable that there should be much greater facilities for the expert reprcsentation of the various classes of women workers in the International Council. It was not possible that only three delegates could cfficiently voice the needs and aspirations of great bodies of professional and industrial workers, and speaking as a trained nurse she must confess that deeply as she respected the three British delegates who took part in the last Quinquennial, she could not feel they were qualifled to deal with nursing questions had these arisen.

There is no doubt of the need of increased representation of National Councils in the International. The United States, for instance, at the Berlin meeting in 1904, will be entitled to three delegates only. All the various branches of work in which women are engaged,-political, philanthropic, professional, and industrial,-cannot thus be adequately represented, as they should be.

\section{THE NATIONAL COUNCIL OF NURSES.}

The Matrons' Council has given much time and thought during the past six months to the best plan of organization for the National Council of Nurses. The Executive Committee, after careful study, sent in a report to tbe council which may be summed up as follows:

"It being felt to be important that the matrons (representing tbe superin. tendents of this country) should be adequately yet not unduly represented, 
it was proposed that an Association of Societics of Certificated Nurses be first formed under some suitable inclusive title, and that this society, when formed, should affiliate with the matrons to form a National Council of Nurses, in which these self-governing societies would be represented by delegates." This report was favorably considered by the matrons at their November meeting, and steps were taken to carry out its provisions.

A constitution for "The National League of Certificated Nurses of Great Britain and Ireland" is, consequently, now under revision, its objects being set forth as follows: "To establish and maintain a code of ethics; to elevate the standard of nursing education; to promote the usefulness and honour, the financial and other interests of the nursing profession."

The qualifications for membership are as follows:

"Associations of nurses having the following qualifications will be eligible for affiliation with the National League:

"1. Associations composed of graduates of schools of nursing connected with general hospitals of not less than fifty beds, giving three years' full training in the wards of the hospital, and certification after examination.

“2. Associations, composed of graduates of schools of nursing connected with Poor Law infirmaries of not less than two hundred beds, giving three years' full training in the wards of the infirmary, and certification after examination, and whose training-schools are recognized by the Local Government Board,

"3. Professional associations of nurses formed for the benefit of nurses, the members of which hold the qualifications of training as defined above."

The growth of the National League will probably be slow, but its pro. moters will be satisfied if it unites those nurses who value professional freedom and who realize that with organization comes responsibility.

\section{TIIE HOSPITAL COMMISSION.}

Much interest has been taken in the Royal Commission on South African Military Hospitals and in the evidence of Mrs. Richard Chamberlain, who, after working at the Cape for ten months, brought a very serious indictment against the Army Medical Department.

Her chief points were its general state of disorganization, want of method in classifying patients, lack of appliances and of adequate nursing arrangements, wasteful housekeeping owing to lack of supervision, defective sanitary arrangements, culpable carelcssness in the treatment of lunatics, and the fact that army doctors removed from hospitals for drunkenness were sent home in charge of invalids on transports.

Mrs. Chamberlain's chief complaint was against the present system of military hospitals, from which these evils in her opinion arose. Being in no way bound to secrecy by the bonds of official etiquette, she was able to speak quite frankly. Her evidence, which was wonderfully lucid, is a curious contrast to the silence maintained by the Army Nursing Service Reserve, and to the approval of present conditions expressed by members of the R. A. Medical Corps.

Distressing as are all these exposures, one may hope that the complete reorganization of the Army Medical Department and of the Nursing Service and Reserve will be the result. The new Secretary of State for War, the Rt. 
Hon. St. John Boderick, has the chance of a lifetime in his present opportunity to provide for the empire's soldiers the best medical treatment and nursing care, which a grateful nation is eager to supply.

Yours cordially,

\section{UNION JACK.}

[The story of the recent action of St. Thomas's Hospital, London, in revising and raising its requirements is held over until the next number.-ED.]

\section{FROM OUR CORRESPONDENT IN ITALY}

\section{Ospedale Climico, Napleg, Italy.}

... Have I told you how I started my school with three nurses, one of whom soon left, and tbe otber two were so well satisfied witb themselves tbat they sailed through tbeir ward work superciliously, and listened to my tbeoretical lessons with a scarcely veiled smile of pity at the idea of my taking so seriously wbat appeared to them to be elementary knowledge?

I had not at tbat time an official position, which made my bumiliations all tbe harder to bear. The revolution took place during my summer boliday, . . . and a new set of doctors was elected, who knew me and upheld my authority. I was now officially accepted as bcad nurse of-nobody exactly knew what; my position grew of itself, and I have crept up by slow degrecs, gaining or losing ground according as I bave won or lost the innumerable little battles which I fight every day. . . . My subordinates are the cross of my life, although we are excellent friends, because tbey do not and never will understand so much as the elements of discipline. . . .

When I returned to Naples in September I found that the Princess Sthe president of the Committee for the Promotion of a Training-School for Nurses, had been busy all tbe summer publishing articles and getting up subscriptions; the result was that there were fourteen new pupils waiting for me besides tbe three who had begun in June. Of all tbese, ten bave just passed tbeir junior exams. Lest $I$ be accused of deliberately departing in my system from the time-honored methods of Alma Mater, let me protest that to make any way at all I must insert tbe thin edge of the wedge and not the thick one. Any other course would most assuredly end in my offending irrevocably the customs and prejudices of the country.

After much discussion among themselves, my suggestions being waived aside, the staff made out a programme of theoretical work. It was decided tbat there should be an hour's lecture given daily to the nurses by the physicians, the first-year subjects being anatomy, physiology, hygiene, surgical and medical pathology; the second-year subjects, gynæcology and obstetrics, diseases of children, first aid to tbe injured, disesses of the eye and ear, and dietetics.

On discussing the position of my pupils (Blue Cross nurses) in the hospital, I could not obtain the dismissal of a single one of the existing " servant-nurses." The result is that my pupils' ward work has never been anytbing but voluntary, for if they do not do up tne patients, there is always some one else to do it for them. ...

My pupils come on duty at eight A.M., coming in from their homes, where- 